\title{
MILLENNIALS GREEN AWARENESS
}

\author{
MOH'D KHEIR ALAMAIREH
}

\begin{abstract}
As the huge human dependency on energy sources, the human have developed many technologies in different sectors. Also the infrastructure that developed very fast renewable energy resources crossed huge milestones and developed very fast as well in the past years. Still among people increased awareness and the news sharing trends especially in the social media era, forced many governments, businesses and people to start developing more green alternatives. As the future especially with the current challenges is going to be green, and those who are operating their businesses without a competitive, sustainable and green strategy are most probably going to be kicked out from the market in the near future.

The aim of this study curried out at Eszterházy Károly University, Hungary is to observe Millennial from different backgrounds, cultures and experiences as well as fields, green awareness, in addition to that, observing their feedback and thoughts about the challenges, what is causing them, how they can be addressed now as well as in the near future and their understanding of the current governmental, industrial as well as individual efforts that they are being put into action, to measure their willingness to contribute to that and how important do they think those efforts and how much it can help in addressing the problem.

The results showed an insufficient understanding of the problems as well as the available solutions to tackle the problems. In addition to that, lack of appreciation to the current efforts put into addressing the problem. Still they showed great willingness to be an active part of the solution even though they have no clear idea of how they can achieve that. Through qualitative interviews and observational methods these conclusions were drawn.
\end{abstract}

Keywords: millennial, businesses, environment, renewable, non-renewable, students JEL Code: $Q 18, Q 42$

\section{Introduction}

Sustainability has become a popular word in the last few years, not only among the scientists but also among the general public and business sector as well. Nowadays, there are several definitions of sustainable development (SD) in the different literatures but the well-known and the most widely accepted definition originates from Brundtland [SNEDDON et al., 2006; GATTO, 1995]. The origin of sustainability was mentioned in the book: Our Common Future in 1984 when the Brundtland Commission first sat down together in Geneva. Brundtland's definition of SD emphasizes invoking the needs of future generations counterbalanced to the current unmet needs of much of the world's population [BOROWY, 2014].

Nowadays, all disciplines and economic sectors are putting sustainability in the focus of their activities. So, there are many good examples at the field of business sector and in consumers' buying habits, too.

The consumers' interest in short supply chains (SSCs) and direct sales from producers has increased due to the positive sustainability attitude. The reason is the extensive production methods and short transport distances [KISS et al., 2019; KISS, 2018]. The behavior of 
consumer may be different. Demographic factors, such as social status, marital status, gender and qualifications can, or their phase of life (their role in life) can be determining.

Females - because of their particular social roles (motherhood, taking care) may be more altruist and hence may be more environmentally and sustainability conscious and more sustainable and prefer local food which is intensified in their realized behavior as age advances [BENEDEK, 2012].

Some electricity companies, for example, now publicly state goals for energy generation from sustainable sources such as wind, hydro, and solar. Millennial have many characteristics that promotes sustainability such as the social conscious, technology-based thinking, optimistic, educated and knowledgeable, health conscious, financial conscious and spiritual conscious, all those suggests that Millennial can promote sustainability on the environmental level more than any previous generation could. Evidences for rapid climate change are compelling, global temperature rises; the planet's average surface temperature has risen about ( 0.9 degrees Celsius) since the late 19th century, warming oceans; with the top 700 meters (about 2,300 feet) of ocean showing warming of more than 0.4 degrees Fahrenheit since 1969; shrinking ice sheets; The Greenland and Antarctic ice sheets have decreased in mass. Sea level rise; global sea level rose about 8 inches in the last century. The rate in the last two decades, however, is nearly double that of the last century and is accelerating slightly every year; declining arctic sea ice; both the extent and thickness of Arctic sea ice has declined rapidly over the last several decades and finally multiple extreme events that occurred all around the globe. [NASA, 2019; HANSEN, 2004]. The utilization of green energy is one of the most promising approaches for humans to do something about climate change, and reduce it is effects, especially on the long run and for the next generations, of course combined with more awareness as well as less damage to the environment in other terms than only energy consumption, such as recycling and using less Plastic for example. Renewable energy, often referred to as clean energy, comes from natural sources or processes that are constantly replenished. For example, sunlight or wind keep shining and blowing, even if their availability depends on time and weather. Solar, or photovoltaic (PV) cells are made from silicon or other materials that transform sunlight directly into electricity. Distributed solar systems generate electricity locally for homes and businesses, either through rooftop panels or community projects that power entire neighborhoods. Solar farms can generate power for thousands of homes, using mirrors to concentrate sunlight across acres of solar cells, in addition to many other renewable energy generation resources [HAN-ANSARI, 2012, JORDEHI, 2016].

\section{Literature review}

\section{Understanding environmental problems}

Sustainable development has become a term that is widely used, although in life it is very problematic term which different groups use in different ways to serve their own purposes. Still, it is very denomination was a compromise between the development imperatives of businesses and of nations in the world heavily dependent on the natural resources for foreign exchange, with environmental conservation interests. [BUCKINGHAM-TURNER, 2008].

Sustainability and development are actually two different concepts which belongs to different worlds. Sustainability is about being careful and concerned about environment, it speaks about the ethics of self-restraint. Development is an act of control, representing two major agents agreeing contractually to meet sustainable goals. Sustainable development has become a common language among businesses and industries. Also, governments suggest, that it has become a potential to offer technological fixes sufficient. 
Within the frame of environmental justice, this raises the questions of environmental damage and who bears the cots regarding them. The increased footprint of many developed and developing countries as well, as well as the political power of some governments as well as organizations like the World Bank can mean that they are still relevant to the problem.

"Corporations operating in a market economy environment do not only aim at profit maximization as they have already realized that their performance depends on the sustainability of the environment and society. Capitalism offers ever so many possibilities, opportunities for corporations to be socially responsible" [BENEDEK et al., 2014. p.1].

"MATHIS WACKERNAGEL [1998], one of the original developers of the ecological footprint concepts, stresses the strength of ecological foot printing as enabling planners, individuals and communities to visualize the human impact on the earth in order to begin to minimize this. He admits that it is not a precision tool, but one which offers a way of measuring ecological sustainability by calculating the resources people consume as well as the waste they generate and the biologically productive area needed to provide enough space for this" [WACKERNAGEL, 1998].

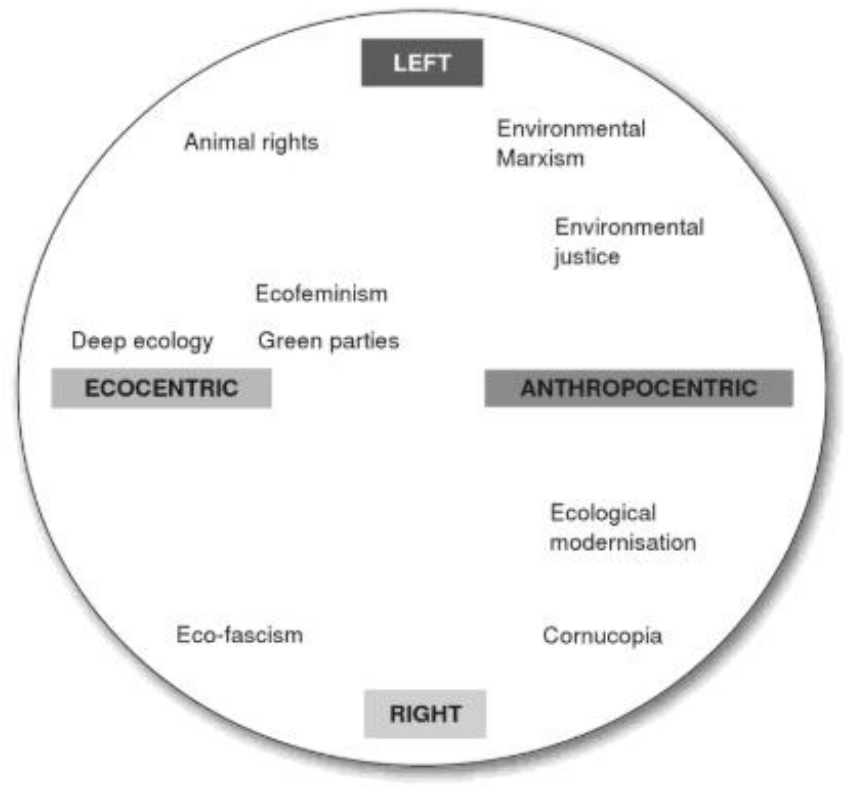

Figure 1: Approaches to the environment

Source: Buckingham, S. and Turner, M. 2008.

As Anthony Giddens in Beyond Left and Right has argued (Figure 1), the environment is progressively an example of a modern issue which breaks typical political pigeon-holing, with politicians from most political parties racing to the middle ground of ecological modernization [BUCKINGHAM-TURNER, 2008]. History of environmental movements in the world and specifically in USA and Europe showed that environmental concern has followed the two trajectories of conservation and public health. First, these are linked in that the spread of industrialization in it is various forms, was seen to threaten wilderness and rural landscapes. Continuous movement in the $19^{\text {th }}$ century had put extra strain on the little urban infrastructure that already existed, and the lack of access to clean drinking water and sewerage combined with poor housing conditions and overcrowded [BUCKINGHAM-TURNER, 2008] 
Table 1: Percentages of people very worried by selected environmental issues in 2002

\begin{tabular}{|c|c|c|c|c|c|c|}
\hline Environmental concern & Male & Female & $\begin{array}{c}\mathbf{1 8}- \\
\mathbf{2 4}\end{array}$ & $\begin{array}{c}\mathbf{4 5 -} \\
\mathbf{6 4}\end{array}$ & Degree & $\begin{array}{c}\text { No } \\
\text { qualification }\end{array}$ \\
\hline Global warming & 43 & 49 & 42 & 46 & 44 & 47 \\
\hline Natural resources depletion & 21 & 24 & 20 & 26 & 22 & 25 \\
\hline Household waste disposal & 27 & 38 & 26 & 34 & 26 & 40 \\
\hline Radioactive waste & 59 & 62 & 59 & 66 & 53 & 60 \\
\hline Toxic waste & 62 & 70 & 56 & 72 & 59 & 70 \\
\hline Ozone depletion & 46 & 53 & 46 & 54 & 48 & 48 \\
\hline Tropical forest loss & 49 & 46 & 40 & 54 & 52 & 48 \\
\hline Drinking water quality & 35 & 42 & 39 & 37 & 32 & 43 \\
\hline
\end{tabular}

Source: Own construction, based on DEFRA, 2002; HMG, 1998.

Areas led to many diseases (Table1). This resulted in wide range public movements especially that the countryside was also being left and impacted with all the factors mentioned earlier.

\section{Understanding green solutions}

Nowadays, the whole world discusses climate change and the importance of taking actions to reduce our ecological footprint. As a consequence, countries intervene out of responsibility for their population and individuals for the sake of their children but companies and businesses, why should they take action? Actually, there are many reasons (Figure 2). Frequently mentioned are the obvious benefits for the environment and health, which are very profitable in terms of reputation. Moreover, businesses can gain competitive advantages from process optimization, cost savings and risk mitigation. Indeed, the financial world is always seeking investments with the lowest risks. As a matter of fact, most banks favor green-minded businesses when attributing loans. The above advantages are more tangible but other lesser known benefits can ensue from green decisions. Eco-friendly measures lead to a higher labor productivity. When adapting to environmental standards, a company undergoes organizational changes and then experiences an increase in training and in interpersonal relations. All this has proven to be very effective in boosting the employee's productivity. Besides, people tend to feel better about their company and therefore become ambassadors for their workplace. Today, being green attracts a higher number of employees, especially young people, and additionally appeals to new clients preferring green partners over conventional industries [DJANOGLI, 2018]. 


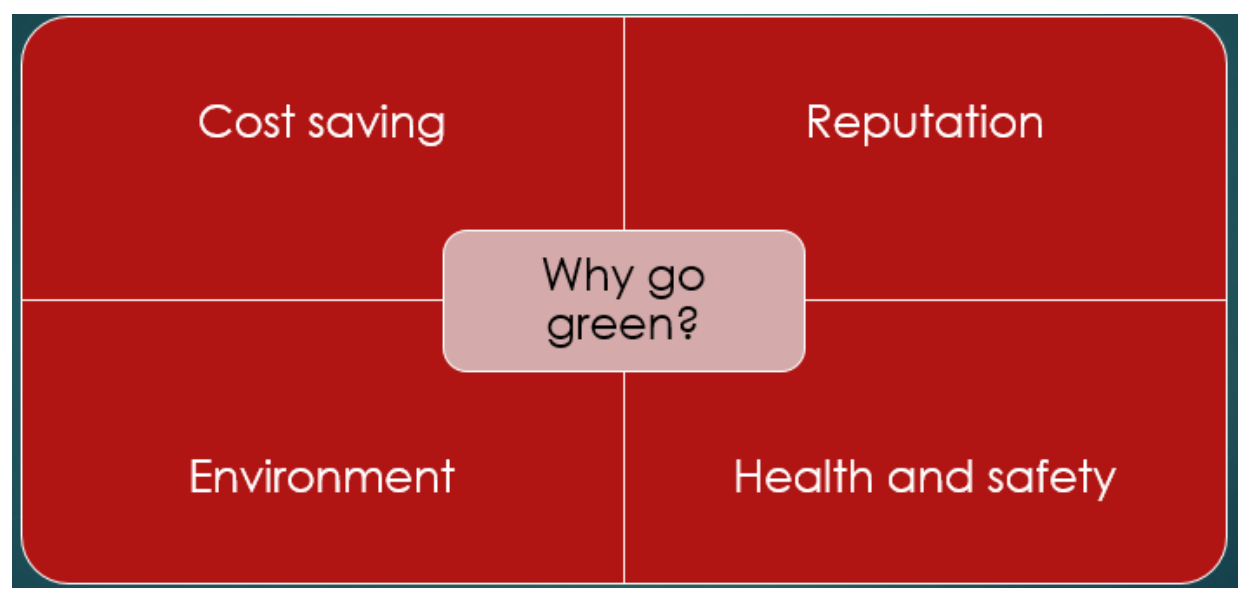

Figure 2: Why go GREEN

Source: https://www.greenfish.eu/

Switching to green energy solution andlor utilizing them in addition to already existing nonrenewable energy resources is actually a process that include multiple steps. First of all screening the current situation, types of energy being used at the current time, investment as well as operation and maintenance costs of the current energy resources afterwards one can proceed to spotting new opportunities either to replace andlor combine other resources that would reduce costs among other advantages as discussed earlier an finally implementing technical first and behavioral changes as a last step (Figure 3).

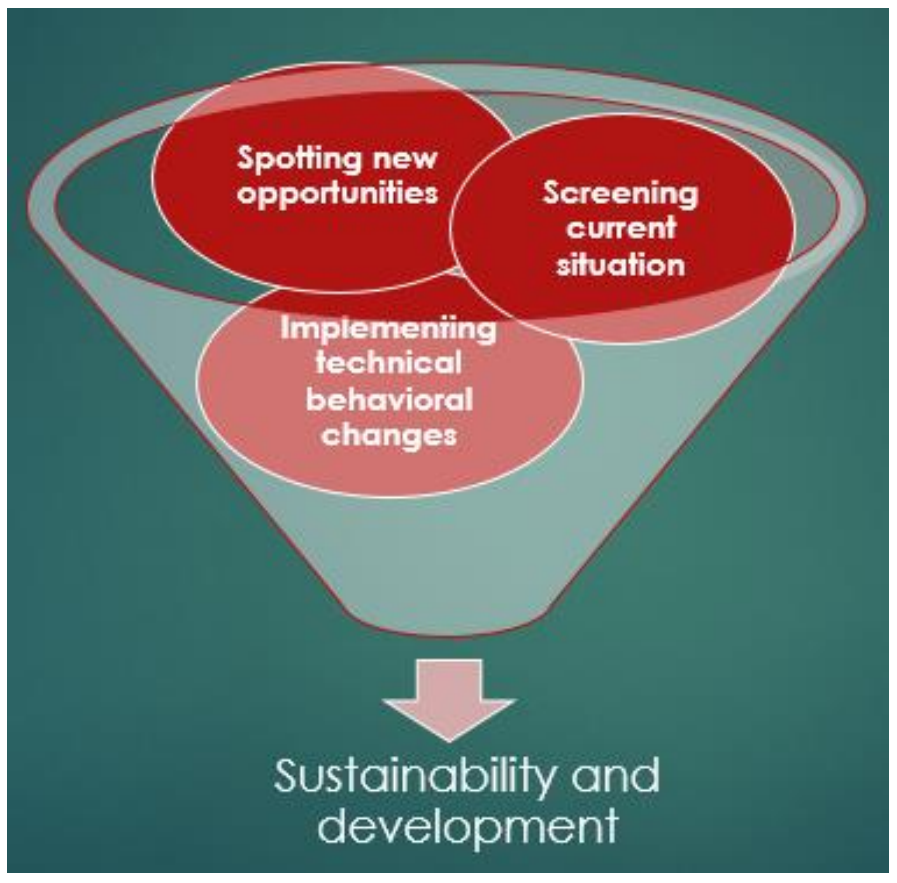

Figure 3: Process of going green

Source: https://www.greenfish.eu/

Also, Green product innovation has been known as one of the key factors to achieve growth, environmental sustainability, and a better quality of life (Figure 4). Understanding green product innovation as a result of collaboration between innovation and sustainability has become a strategic priority for theory and practice. [DANGELICO-PUJARI, 2010]. 


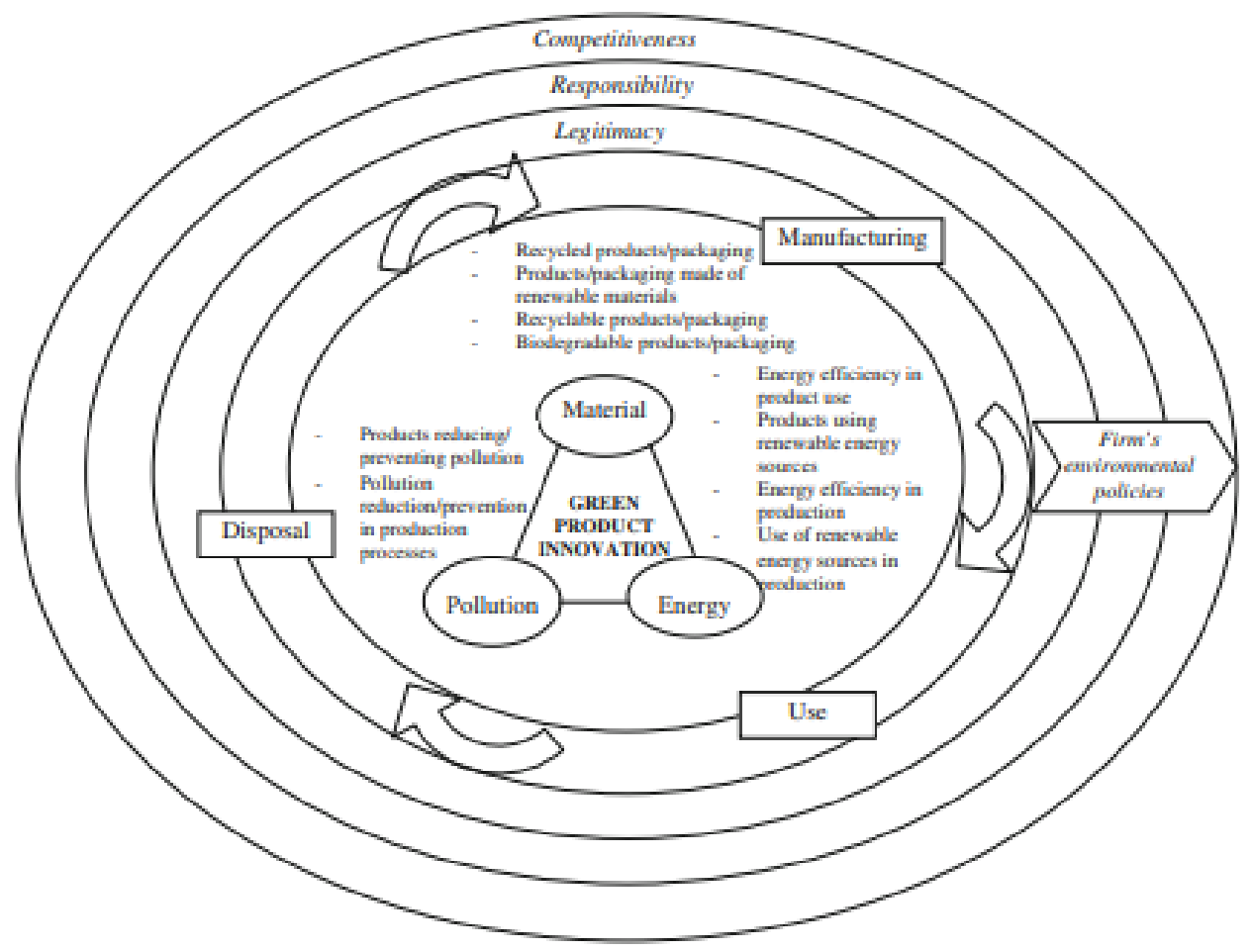

Figure 4: A conceptual framework for green product innovation Source: Dangelico-Pujari 2010.

Renewables are increasingly replacing "dirty" fossil fuels in the power sector, offering the benefit of lower emissions of carbon and other types of pollution. Still not all sources of energy sad to be "renewable" are beneficial to the environment. Biomass and large hydroelectric dams create difficult tradeoffs when considering the impact on wildlife, climate change, and other issues. Renewable energy, often referred to as clean energy, comes from natural sources that are constantly replenished. As an example, sunlight or wind keep shining and blowing, even if their availability depends on time and weather. Nonrenewable, or "dirty," energy includes fossil fuels such as oil, gas, and coal. Nonrenewable sources of energy are only available in limited amounts and take a long time to replenish. When we pump gas at the station, we're using a finite resource refined from crude oil that's been around since long times ago [NSCI].

\section{Willingness to switch to green energy resources}

Life is directly associated with the quality of the natural environment and the availability of natural resources. Environment and life are interdependent concepts. Maintaining a balance in the sphere ecosystem is a basic prerequisite for preserving life. The atmosphere of earth is a valuable and sensitive resource to be protected. On the opposing, undesirable inflows into the ecosystem, caused by anthropogenic activity, can shake this harmony and degrade living conditions. Human influence on the environment is increasing due to mass production of technological goods, intensification of agriculture, the rapid rate of urbanization, and growing demand of fossil fuels for energy and transport. Hence and from here raise the importance of substituting nonrenewable resources with renewable ones and reducing ecological footprint. Social acceptance of green funds is monitored at both national and local levels, as it has been observed that citizens' attitudes may vary, not only between countries but also between regional 
entities of the same country. The front-runners in renewable energy production are Denmark and Germany. In the latter, more than $42 \%$ of electricity generation is produced by renewable sources. In South Korea, active ecological awareness has been reported among citizens; most of them support strategies which promote renewable forms of energy that remain state-owned. Similarly, both the federal and the state US rules are further motivating consumers through tax credits and discounts, so that the energy end-users can install solar energy systems. In Portugal, there is a positive attitude towards innovative RES investments, and this social behavior is more pronounced for solar projects and new hydropower units. The nations with the largest installed photovoltaic rated power are Germany, Italy, USA, China, Japan, Spain, France, Belgium, Australia, and the Czech Republic. These countries are mainly drawing their energy policies upon KWh guaranteed prices, in the Netherlands, volunteers and local authorities play a very important role in the technological spur and large-scale applicability of photovoltaic. [NTANOS et al., 2018].

According to the research of [KONCZ, 2015] in Hungary are in the beginning stage of energetic biomass utilization, and the local and regional co-operations among economic and administrative actors are missing or incidental. Comparing the Hungarian to the German situation it can be stated that the energetic utilization of the biomass mobilizes is better organized.

In other parts of the world such as the Middle East and Arabian Gulf and parts of Africa, one can clearly see that there is an effort on all levels, whether governmental, industrial andlor individual levels to adapt to a green tomorrow starting now, and different renewable energy resources are being utilized ad implemented in different parts of these regions as well. A global willingness regardless to the challenges and on multiple levels can be witnessed.

Contrarily, a significant aspect that inhibits the wider adoption of RES-based energy systems, apart from the high cost of infrastructure, is the lack of publicly shared information and the behavior of citizens against RES technological advancements. This social behavior has mainly been observed in economically developing areas or nations. Lack of evidence was reported in residents of rural, suburban, and urban areas in the Chinese context. Another study was deployed in the Malaysian context, about views and perceptions of the local population towards solar energy and the installation of photovoltaic; it was concluded that the Malaysians hardly understood the incentives and the wider socio-economic benefits derived, thus they were unwilling to invest in photovoltaic. Moreover, in the Middle East and North Africa, the feature of social resistance was reported among interviewed citizens, since they communicated a biased behavior, meaningfully distorting anything that tends to become socially acceptable. On the other hand, a study about the social approval of small hydropower plants (SHP) in India exposed that SHP projects are nationally challenging practices that can be directly utilized in the Indian energy mix of manufacture. At a distance from social acceptance, many studies focus on the economic amount a consumer is prepared to pay for further expansion of RES in their area of residence, which is defined as willingness to pay (WTP). For estimation of the economic value that an individual hypothetically assigns to a non-market good, such as WTP for renewable energy, the contingent valuation method (CVM), is commonly used. In this method, the respondent is directly asked usually through a questionnaire survey, to state his preference. A positive relation has already been identified between WTP, income, and level of information.

In a study examining approaches on the road to RES, Australian tourists were eager to pay $1-5 \%$ more for the presence of renewable energy systems within their housing units. For the case of Sweden, by using binary logistic regression, it was found that people with increased environmental awareness are more likely to accept renewable energy. [NTANOS et al., 2018]. Here comes within all that the Millennial willingness as the future leaders, affected and inspired by the previously mentioned points in addition to their knowledge, awareness and most importantly their financial situation and power to take decisions either on an individual level, 
business level andlor governmental level. As Millennial nowadays are all in an age group where their decision power might not be as strong as baby boomers who are actually still very much involved in all aspects of life from the individual up to the governmental levels passing by the business an industrial level as well.

\section{Understanding of public, business and governmental roles}

Governmental sector spends public money while procuring products and services. The amount of this public money is representing around 19\% of EU GDP. By spending such large amount of money, the authorities could have a significant impact on the market and could create demand and actually show a good example. Potential of green public procurement as a policy has been increasingly recognized at national, EU as well as international levels. For example the figure below demonstrates the department of energy in the USA share of funding for different energy resources including renewable energy [Interreg Europe]

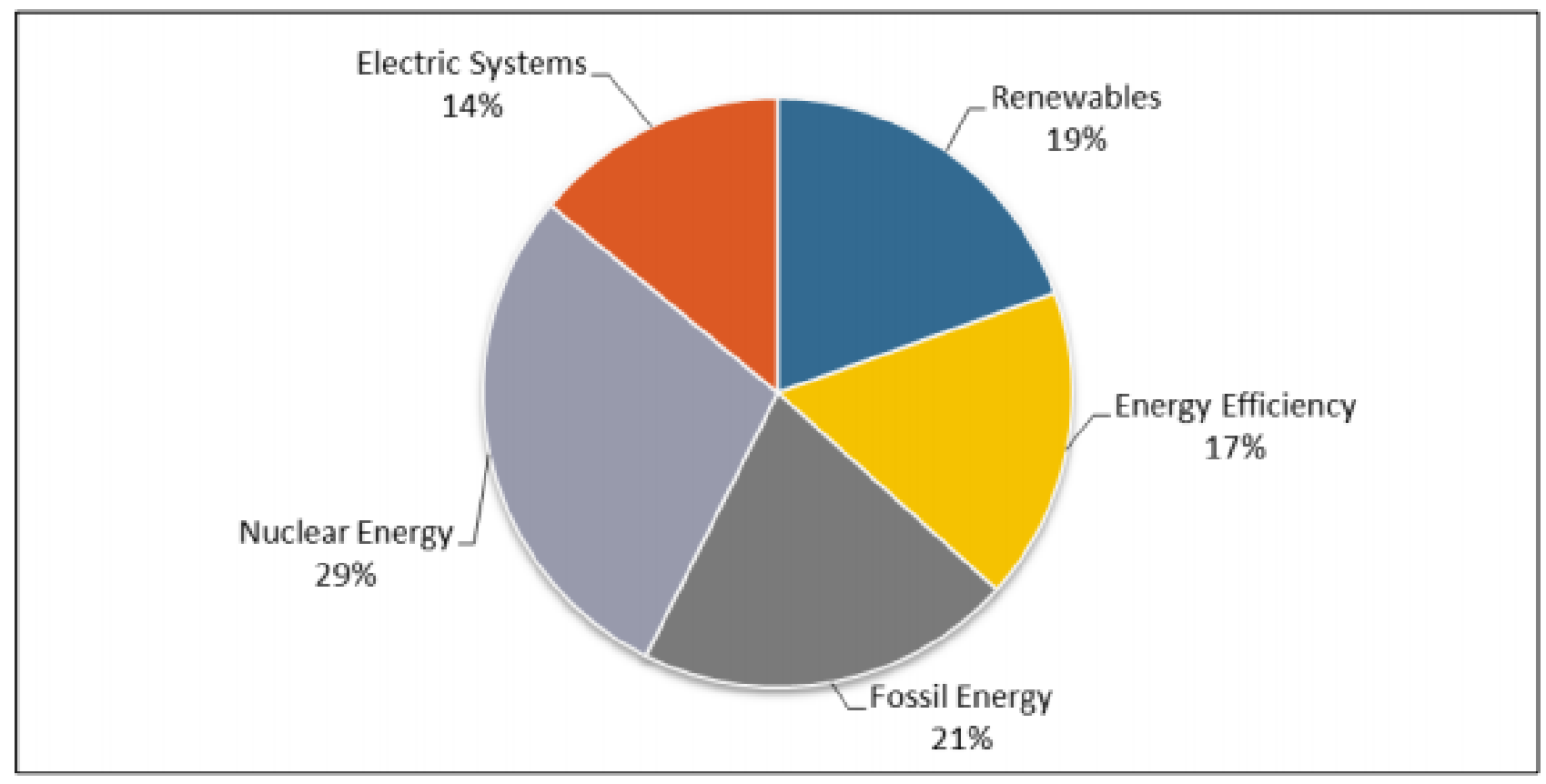

Figure 5: DOE Energy technology share funding 2009-2018, Source: Corrie E. Clark, 2018

When it comes to the public, many factors play in their role, for example the demographical location, background knowledge about RES as well as education and professional experience, for example the figure below demonstrates a sample of the public sector from Saudi Arabia and their willingness perspective to adopt RES (Figure 6). 


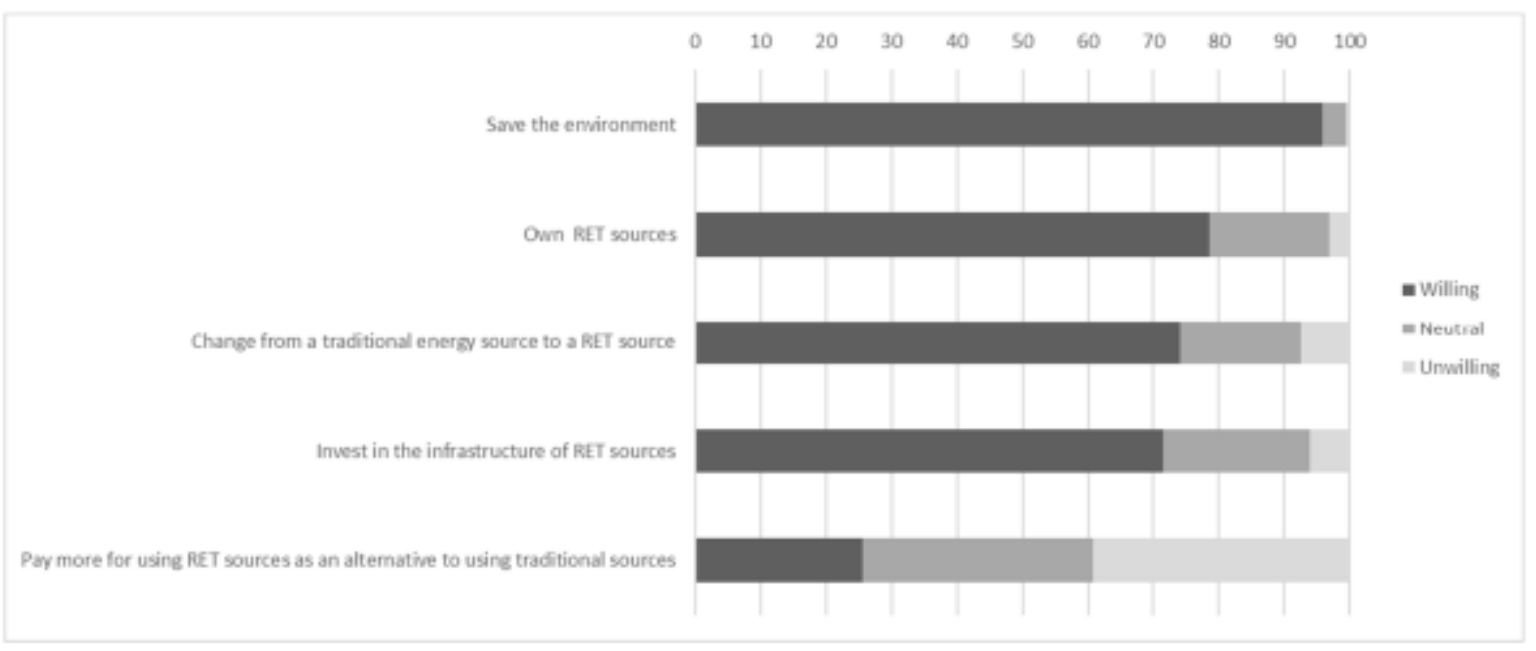

Figure 6: Willingness perspective to adopt RES percentages

Source: Mosly-Makki, 2018

As it could be seen from the figure above the public perspective changes, and it is due to the factors mentioned earlier, and here comes the government as well as industry role to educate, market and encourage his adaptation, and not only adopting it, but also adopting it for the right reasons. With a yearly US\$5-7 trillion required to sponsorship the SDGs only (according to UNEP), and a projected US $\$ 90$ trillion needed to funding the aims of the Paris Agreement over the next 15 years (The Climate Group), industry has a critical role to play as a source of investments and as a driver of technological development and innovation, not to mention as an engine for economic growth and employment. To stand a chance of limiting our planet's temperature rise to below $2^{\circ} \mathrm{C}$, adding to many other associated risks, investments to address climate change and pursue clean energy become some of the most important investments needed in the near future - and the business case for addressing these issues is clear. Our impact on nature is passed over too often in the global fight against climate change. At this year's IUCN World Conservation Congress in Hawaii, the significance of moving the conservation agenda forward was emphasized by all stakeholders. The necessity to invest in nature to preserve our chances to fight climate change and provide enough for the growing population to develop sustainably is well understood by non-state actors. However, while the private sector's engagement in global conservation efforts is on the rise, the business case for investing in nature is not yet fully understood. If the private sector starts integrating nature in its business approach and its impact on the natural environment, others will follow suit [BAKKER, 2016].

The spread of utilization of renewable energy resources is primarily motivated by objectives of energy policy and climate protection. However, the rural and community development role of the new investments had got a greater significance in the past years [KONCZ et al., 2015].

\section{Willingness to start new green businesses}

Superficially, there has seemingly never been a better time to launch a sustainable influence. Customers, predominantly Millennial, increasingly say they want products that embrace purpose and sustainability. Undeniably, one recent report revealed that certain categories of products with sustainability claims showed twice the growth of their traditional counterparts. Yet a frustrating paradox remains at the heart of green business: Few consumers who report positive attitudes toward eco-friendly products and services follow through with their wallets. In one recent survey $65 \%$ said they want to buy purpose-driven brands that advocate 
sustainability, yet only about $26 \%$ actually do so. [WHITE et al., 2019]. Never the less, the increasing awareness, education and challenges as well as increasing environmental risks and more red ocean business and hard, competitive markets, new entrepreneurs are looking for more competitive ways and more blue oceans, and from this perspective raises the increased willingness to start more competitive green businesses. Not only are that, but even already existing.

Business transforming to be more competitive on the short run and of course sustainable on the long run. Figure below for example demonstrates existing business who acquired Eco label products award during the past (Figure 7).

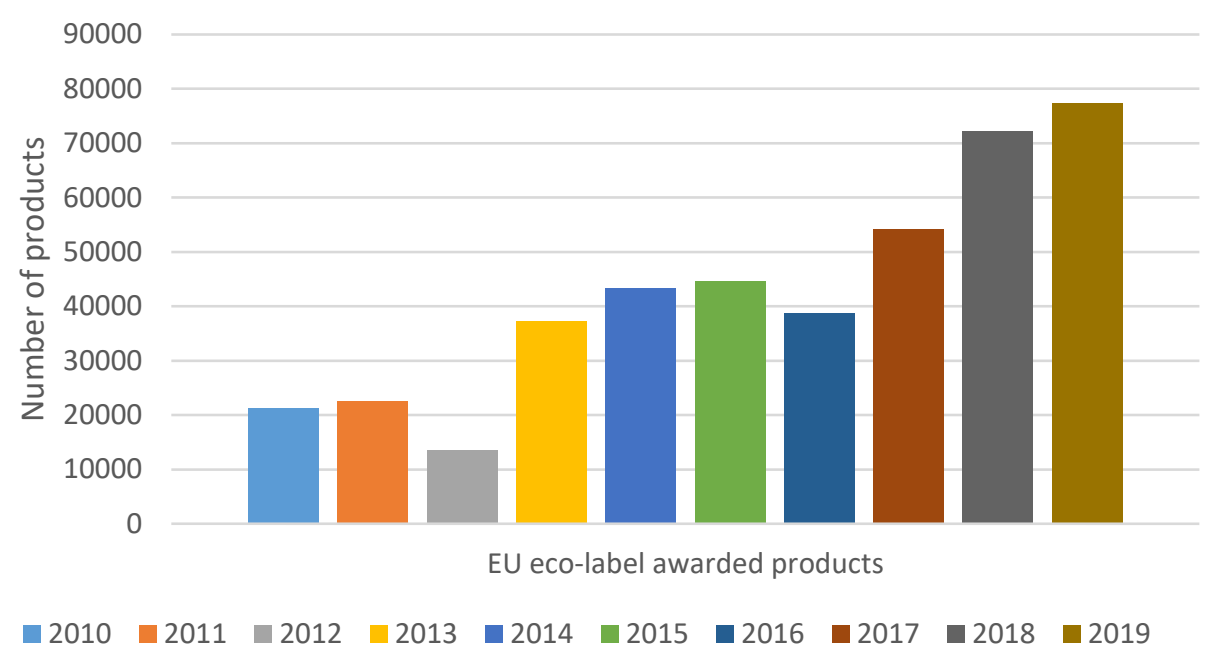

Figure 7: Evolution of the number of EU Eco label products 2010 - 2019, Source: Own construction based on https://ec.europa.eu/environment/ecolabel/facts-andfigures.html

\section{Method and sampling}

The study achieves it goal through a qualitative research, where participants from different educational, professional as well as cultural backgrounds were interviewed and recorded while being asked about the factors discussed earlier. The depth interviews were conducted in Heves County, in Hungary, where some of the interviewees were only students (bachelor and master levels) and some of them were also working on part time basis next to their studies. The question were carefully studied before it were included in the interview, to make sure they study and address the points discussed earlier in the literature and later in the results section. The interview started with an introduction gauging general outlook on the participants' opinions and knowledge and then went deeper. All questions were open ended to make sure the participants could freely represent thoughts and these thoughts were later on studied and analyzed.The data processing of the depth interviews and information processing were carried out in an oral way as well as observational way.

As for the characteristics of the sampling, student from Asia, Europe, Middle East, Africa and Eurasia and studying on different levels (bachelor and master programs) ranging from but not limited to fields like agricultural engineering to leadership management and business development and some of them working on part-time basis as at commercial fields, technical fields and operational fields as well. The target group was very diverse and colorful and this for sure helped to draw more concrete conclusions and results. 


\section{Results of the research}

\section{Understanding environmental problems}

When it comes to the understanding of the environmental problems, it was noticed that the level of understanding of the interviewees was very basic with no in depth realization of the near as well as far dangers that is facing and going to face human beings for many generations to come if not addressed. As the interviewees had no clear idea about sustainability and how one can be sustainable and how the sustainable development can be applied and reflected into everyday life aspects. As this was not expected, the main reason behind this was seen to be and as mentioned by the interviewees the lack of education, initiatives as well as marketing, since they all mentioned and showed interest in the topic and the majority of the interviewees even stated that they don't even feel safe within the current human huge dependency of non-renewable energy resources. The interviewees did recognize what does the term ecological footprint means, what does it represent and how it can be used in order for individuals and even business to be more green, and aim to reduce the ecological footprint. It is hard to say that everyone shall know what does the term ecological footprint means and how it can measured and used, still as Millennial have all the resources to get educated more about the topic it was shocking that all interviewees responded with: What does ecological footprint means?

\section{Understanding green solutions}

There is a variety of green solutions, and by green solutions it is not meant only the implementation of renewable energy resources, but also the adaptation of more efficient lifestyles supporting green products in addition to supporting green businesses and initiatives. It was concluded that the interviewees had very basic understanding of green energy solutions, and they all linked it to physical solutions, that is renewable energy resources with Solar followed by Wind energy sources being the most dominant and mentioned by the interviewees, with very little realization of the technical as well as financial background behind it. This comes from the huge implementation and adaptation of these resources by many governments, industries as well as individuals all around the globe, as when asked why they knew these two specific resources, the majority of the interviewees mentioned that it was due to seeing it all around in their countries and even abroad, especially interviews who are Europeans, Africans and Middle Eastern. This proofs the fact that governments and businesses do have a leading role in the process as public is actually observing and learning accordingly, excluding the part of the public who has the scientific andlor practical knowledge through fields of education andlor work.

Very little number of the interviewees realized the daily lifestyle effect on the environment, what one eats, type of transportation or which products one buys. As the students were shown images and asked what comes to their mind when looking at the photos, very little number of the interviewees recognized the Eco-friendly product stamp, and the majority didn't realize what it means and mentioned that they never saw it before, especially interviewees from Africa. Still all interviewees agreed on the financial part of the green solutions, as they all mentioned that it would for sure be more economic and reduce the total cost and expenses of a household or a business as well as they agreement of its health benefits, which is considered very promising as they can see the cost cut through implementing such solutions as well as the positive health effects that can be witnessed in return and the environment and atmosphere improvement. 


\section{Willingness to switch to green energy resources}

Starting from their understanding to the financial savings, health improvement and less environmental damage, all participants showed great interest as well as willingness to switch o green energy resources in their households and wherever they can take the decision to make it, still when asked if any of them have it back at home, they all answered negatively, and as they are still financially independent, this was totally not shocking, as still they are still living under the baby boomers wings. Also this shows the different ways of thinking and the better understanding of Millennial when compared to baby boomers when it comes to the importance of implementing such solutions, as none of the baby boomers they are living with took the decision to install such resources. Still this can be based upon, since the financial situation of their families back at home is unknown, so maybe the reason behind that is the inability to put the initial investment in the first place. Regardless, all participants showed great interest and willingness to implement green solutions as physically, still when it came to the lifestyle, very few of them agreed, that yes it can be better for the environment of one reduced the ecological footprint (after it was explained what it means to them). Very few of them showed willingness to change lifestyles and improve wherever possible. The rest considered that it is more government andlor businesses role and their simple contribution wouldn't really make a difference if it was scientifically true, but even worst, is that the majority didn't even believe that the lifestyle can play a very important role, and this was a shocking observation, as all participants were Millennial, and it was expected that Millennial already developed that understanding.

\section{Understanding of public, business and governmental roles}

The majority of the participants insisted that it's governments and businesses, who are the most responsible for the negative effects as well as the necessary steps that needs to be taken in order to get back on the right track and set the road for a more green tomorrow and a stable and healthy future and environment for them first and for the next generations as well. Most of the participants mentioned that governments shall spend more money on implementing green solutions as well as marketing them. Also governments shall enforce stricter environment protection laws on businesses and industries from their point of view. When asked about their governments previous actions, current as well as future ones, it was seen that there were no clear information from their side about their governments efforts, but they all agreed that, their governments previous and current actions are still not enough. Still they all were optimistic about their government's future plans, without knowing exactly what those plans are. When asked why, it was noticed that they were very relying on the fact that the situation is very dangers now, and for sure governments realize that, hence they for sure have better plans for the future, and this is considered a critical and dangerous way of thinking as clearly they are excluding them self as an active, young, energetic and educated part of public from the decision making at least for now.

It is true that businesses and governments can have the biggest impact, still this through implementing to lead and teach, this shows that their government efforts are not marketed enough, and it being applied without the clear delivery to the public about how and why those solutions are being implemented. This conclusion was drawn based on the fact that, they all had great interest in the topic, so if information was being shared and marketed, how come those young Millennial didn't know about it. 


\section{Willingness to start new green businesses}

All participants mentioned that, if they were going to start their own business, then it would for sure be as green as possible, and that they would always work for achieving green certifications, through implementing green processes and marketing and selling green products. They all believed that the future market has to be that way, and those businesses that don't have that in their strategic plan have higher risk of failing and being unable to compete in the future. They all also showed their willingness to invest more in a green business rather than saving some money and investing in a non-green business. Also the majority of the interviewees would spend more to buy a green product rather than saving some money and buying a non-green product. This means that Millennial at EKE support green businesses and this is very promising for a more green tomorrow.

\section{Conclusion}

As seen in table 2 below, Millennial (sample) at EKE lack a sufficient understanding of the environmental problems and the associated dangers. Also they lack a sufficient information (financial, technical as well as ethical) about the green solutions including but not limited to the physical ones as well as the lifestyle related ones. Also there is a deep believing that it is mostly government and businesses roles to address these problems and accordingly implement solutions and the role of the public is actually to follow the lead. Still there were willingness to spend more on green products and to invest in green projects and this is very promising for the future, especially if more efforts are put from all sides to educate more Millennial about the topic and increase accordingly their motivation and involvement in the transformation processes as they are the leaders of tomorrow, so they need to build the base now.

Table 2: Millennial's knowledge about the environmental problems and the associated dangers

\begin{tabular}{|c|c|}
\hline Aspect & Status \\
\hline Understanding of environmental problems & Insufficient and shall be developed \\
\hline $\begin{array}{c}\text { Understanding of green solutions } \\
\text { Willingness to switch to green energy resources }\end{array}$ & $\begin{array}{c}\text { Insufficient and shall be developed } \\
\text { Sufficient. Shall be supported with more } \\
\text { knowledge }\end{array}$ \\
\hline $\begin{array}{c}\text { Understanding of public, business and } \\
\text { governmental roles }\end{array}$ & $\begin{array}{c}\text { Insufficient and shall be developed } \\
\text { Willingness to start new green businesses }\end{array}$ \\
$\begin{array}{c}\text { Sufficient. Shall be supported with more } \\
\text { knowledge }\end{array}$ \\
\hline
\end{tabular}

Source: own construction, $2019(N=20)$

Based on the research conducted to create this article as well as the results presented earlier, the following recommendations are accordingly presented.

- Government sector shall market and share more their contributions to the field.

- Business sector shall market and share more their contribution to the field. Besides that the important tool for the sustainability would be the strategic cooperation between companies. According to [TAKÁCSNÉ GYÖRGY et al., 2016], companies have strong strategic cooperation with consumers, but cooperation with competitors and business partners is ad hoc and one-sided. So it would be good to develop the cooperation inside the business sector in the interest of sustainability. 
- Government sector including all its public services shall help the public understand their role in this transformation process.

- Business sector including all its services shall help the public understand their role in this transformation process.

- Educational institutes shall focus on this topic more and help build a concrete base to build upon as the future leaders. Especially but not limited to higher education institutes.

- More research shall be carried on in more parts of the world and at different educational institutes to seize the real situation and come up with a true representation if where Millennial stand and act accordingly.

\section{References}

1. BAKKER, P. (2016): The private sector role in promoting sustainable development. Source: https://www.wbcsd.org/Overview/News-Insights/Insights-from-the-CEO/Theprivate-sector-s-role-in-promoting-sustainable-development

2. BENEDEK A. (2012): Conscious Consumption - Green Consumption. Annals of the Polish Association of Agricultural and Agribusiness Economists, 14(6), 18-23.

3. BENEDEK A. - TAKÁCSNÉ GYÖRGY K. (2014): Responsible Management in the Framework of Market Economy. Wspolczesne Zarzadzanie: Kwartalnik Srodowisk Naukowych I Liderow Biznesu / International Journal of Contemporary Management, 13(3), 8-20

4. BOROWY, I. (2014): Defining Sustainable Development for our Common Future: A History of the World Commission on Environment and Development. Abingdon, Oxon: Routledge.

5. BUCKINGHAM, S. (2008): Approaching Environmental Issues. In: BUCKINGHAM, S. - TURNER, M.: Understanding Environmental Issues. London: SAGE Publications Ltd. DOI: $10.4135 / 9781446215357 . n 2$

6. CLARK, C. E. (2018): Renewable energy R\&D funding history: A comparison with funding for nuclear energy, fossil energy, energy efficiency and electric systems R\&D. Congressional Research Service. Source: https://sgp.fas.org/crs/misc/RS22858.pdf

7. DANGELICO, R.M. - PUJARI, D. (2010): Mainstreaming Green Product Innovation: Why and How Companies Integrate Environmental Sustainability. Journal of Business Ethics, 95(3), 471-486. DOI:10.1007/s10551-010-0434-0

8. DJANOGLY, H. (2018): Why Going Green Can Have a Positive Impact on Attracting Customers Customer Think. Source: https://customerthink.com/why-going-green-canhave-a-positive-impact-on-attracting-customers/

9. GATTO, M (1995): Sustainability: Is it a Well Defined Concept?. Ecological Applications, 5(4), 1181-1183. URL: https://www.jstor.org/stable/2269365

10. HANSEN, J. (2004): Defusing the Global Warming Time Bomb. Scientific American Nature America Inc. 290(3), 68-77.

11. KISS, K. (2018): Hagyományos piacok összehasonlító vizsgálata különbözö funkciójú településeken. Gazdálkodás, 62(1), 62-75.

12. KISS, K. - RUSZKAI, CS. - TAKÁCS-GYÖRGY, K. (2019): Examination of Short Supply Chains Based on Circular Economy and Sustainability Aspects. Resources, 8(4), 161. DOI: $10.3390 /$ resources 8040161

13. KONCZ, G. (2015): The role of solid biomass used for energy purposes in settlement development. Journal of Central European Green Innovation, 3(2), 59-70.

14. KONCZ G. - NAGYNÉ DEMETER D. (2015): Megújuló energia projektek közösségfejlesztő $\quad$ szerepe. $\quad$ Economica, $4(2), \quad 142-151$. DOI:10.47282/ECONOMICA/2015/8/4/2/4601 
15. MOSLY, I. - MAKKI, A. A. (2018): Current status and willingness to adopt renewable energy technologies in Saudi Arabia. Sustainability, 10(11), 4269. DOI:10.3390/su10114269

16. NTANOS, S. - KYRIAKOPOULOS, G. - CHALIKIAS, M. - ARABATZIS, G. SKORDOULIS, M. (2018): A Social Assessment of the Usage of Renewable Energy Sources and Its Contribution to Life Quality: The Case of an Attica Urban Area in Greece. Sustainability, 10(5), p. 15. DOI:10.3390/su10051414

17. REZAEE JORDEHI (2016): Parameter estimation of solar photovoltaic (PV) cells: A review. Renewable and Sustainable Energy Reviews, 61, 354-371. DOI: 10.1016/j.rser.2016.03.049

18. SNEDDON, CH. - HOWARTH, R.B. - NORGAARD, R.B. (2006): Sustainable Development in a Post-Brundtland World. Ecological Economics, 57(2), 253-268. DOI:10.1016/j.ecolecon.2005.04.013

19. TAKÁCSNÉ GY. K. - BENEDEK A. (2016): Bizalmon alapuló együttmüködés vizsgálata a kis- és középvállalatok körében. In: Csiszárik-Kocsir Ágnes: Vállalkozásfejlesztés a XXI. században. Budapest: Óbudai Egyetem, pp. 379-390.

20. TAO HAN - NIRWAN ANSARI (2012): Intelligent Cell BrEathing to Optimize the Utilization of Green Energy, IEEE Communications Letters, 16(6), 866-869. DOI: 10.1109/LCOMM.2012.042312.120486

21. WACKERNAGEL, M. - REES, W. (1998): Our Ecological Footprint. Gabriola Island, United States: New Society Publishers.

22. WHITE, K. - HARDISTY, D.J. - HABIB, R. (2019): The elusive green consumer. Harvard business Review, (July-August), 124-133. Source: https://hbr.org/2019/07/theelusive-green-consumer

23. WILLMOTT, H.C. (2014). 'Science, Governance and Self-Understanding: From Anthropocenticism to Ecocentrism?'. Critical Policy Studies, 8(1), 22-40. DOI: 10.1080/19460171.2014.883858

24. NASA. Source: https://climate.nasa.gov/. Download: 20.10.2019

25. GreenFish. About Us. Source: https://www.greenfish.eu/about-us/. Download: 20.10.2019

26. Europea. Fact and Figures. Source: https://ec.europa.eu/environment/ecolabel/facts-andfigures.html

27. Interreg Europe. Policy Learning. Source: https://www.interregeurope.eu/policylearning/ Download: 16.10.2019

28. Natural Resources Defense Council (2018): Renewable Energy: The Clean Facts. Source: https://www.nrdc.org/stories/renewable-energy-clean-facts. Download: 16.10.2019

29. N-sci Technologies (2019). Top 10 reneweable energy question for 2019. Source: https://nsci.ca/2019/11/27/top-10-renewable-energy-questions-for-2019.

Download:16.10.2019

\section{Author}

\section{Moh'd Kheir Alamaireh}

MA Student, Business Development

Eszterházy Károly Egyetem, Gyöngyösi Károly Róbert Campus

alamayreh.mohammad@gmail.com 